\title{
Growth, Yield Attributes and Yield of Pearl Millet as Influenced by Phosphorus Management Practices in Kharif Pearl Millet
}

\author{
A. Sowjanya ${ }^{1 *}$, Ch. Pulla Rao ${ }^{1}$, K. Mosha ${ }^{1}$, Ch. Sujani Rao ${ }^{2}$ and Y. Ashoka Rani ${ }^{3}$ \\ ${ }^{1}$ Department of Agronomy, Agricultural College, Bapatla, ANGRAU, India \\ ${ }^{2}$ Soil Science and Agricultural Chemistry, Agricultural College, Bapatla, ANGRAU, India \\ ${ }^{3}$ Crop Physiology, Agricultural College, Bapatla, ANGRAU, India \\ *Corresponding author
}

\section{A B S T R A C T}

\section{Keywords \\ Pearl millet, Phosphorus management practices, PSB, Growth, Yield attributes and yield \\ Article Info \\ Accepted: \\ 24 May 2019 \\ Available Online: \\ 10 June 2019}

\begin{abstract}
A field experiment was conducted during kharif seasons of 2017 and 2018 at Agricultural College Farm, Bapatla to evaluate the effect of phosphorus management practices on growth, yield attributes and yield of pearl millet. The seven treatments consisted of $\mathrm{T}_{1}$ : No $\mathrm{P}, \mathrm{T}_{2}: 50 \% \mathrm{RDP} \mathrm{T}_{3}: 75 \% \mathrm{RDP}, \mathrm{T}_{4}: 100 \% \mathrm{RDP}, \mathrm{T}_{5}: 50 \% \mathrm{RDP}+$ seed inoculation with $\mathrm{PSB}, \mathrm{T}_{6}: 75 \% \mathrm{RDP}+$ seed inoculation with $\mathrm{PSB}, \mathrm{T}_{7}: 100 \% \mathrm{RDP}+$ seed inoculation with PSB with RBD design. The results showed that significantly the highest growth (plant height and drymatter production), yield attributes (earhead length and productive tillers per $\left.\mathrm{m}^{-2}\right)$, grain yield $\left(\mathrm{kg} \mathrm{ha}^{-1}\right)$ and stover yields $(\mathrm{kg} \mathrm{ha}-1)$ were recorded with application of $100 \%$ RDP + seed inoculation with PSB but remained statistically on par with the treatment which received $100 \%$ RDP during both years of experimentation and in pooled data. Test weight (g per 1000 seeds) and harvest index were not significantly influenced by different treatments.
\end{abstract}

\section{Introduction}

Pearl millet is an important crop in rainfed areas of India. Among the coarse cereals grown, pearl millet occupies pivotal position in the arid and semi-arid regions of India, occupying an area of 6.98 mha with a total production of $8.06 \mathrm{Mt}$ and productivity of $1,154 \mathrm{~kg} \mathrm{ha}^{-1}$ (Directorate of Economics and Statistics, 2016). In recent times, it is gaining more attention of farmers, researchers and traders in rainfed areas due to increasing evidence of less seasonal rainfall, terminal heat, frequent occurrence of extreme weather events coupled with scanty water resources (Singh et al., 2010). It is traditionally an indispensable component of dry farming region and it is considered more efficient in utilization of soil moisture and has a higher level of heat tolerance than even sorghum or maize crops.

In all major nutrients phosphorus is the essential nutrient for biological growth and development of crop especially for pulses. It is an important constituent of nucleic acids, proteins, enzymes and phospholipids. It is essential for translocation of photosynthates 
from source to sink and important component of ATP, ADP, chloroplast and mitochondria. Phosphorus nutrition is desired and balanced dose enhances cell division and meristematic growth in living tissues, root development, nodulation and hastens maturity (Tisdale et al., 1995).

Inadequate phosphorus supply is considered as one of the major limiting factor in crop production. The situation is becoming more complicated because the natural reserves and the raw materials for the manufacture of phosphatic fertilizers are depleting at a faster rate. All these factors lead to wide spread deficiency of $\mathrm{P}$ for agricultural production, Hence, we need to improve its use efficiency and availability of phosphorus. Under such conditions, use of biofertilizers like phosphorus solubilizing Bacteria (PSB) will increase the bio-availability of native and added phosphorus.

\section{Materials and Methods}

The field experiment was conducted at Agricultural college farm, Bapatla which is situated at a latitude of $15^{\circ} 54^{\prime} \mathrm{N}$ and $80^{\circ}$ $25^{\prime} \mathrm{E}$ longitude, at an altitude of $5.49 \mathrm{~m}$ above the mean sea level. The experiment was conducted for two years during kharif seasons of 2017 and 2018. Experimental soil was clay loam, neutral in reaction, medium in organic $\mathrm{C}$ content, low in available $\mathrm{N}$, medium in available $\mathrm{P}$ and high in $\mathrm{K}$. A total rainfall of $660.9 \mathrm{~mm}$ and $363.2 \mathrm{~mm}$ was received during 2017 and 2018. The experiment was conducted with seven treatments in RBD, with seven phosphorus management practices viz., $\mathrm{T}_{1}$ : No $\mathrm{P}, \mathrm{T}_{2}: 50 \% \mathrm{RDP}_{3}: 75 \% \mathrm{RDP}$, $\mathrm{T}_{4}: 100 \% \mathrm{RDP}, \mathrm{T}_{5}: 50 \% \mathrm{RDP}+$ seed inoculation with Phosphate Solubilzing Biofertilizer, $\mathrm{T}_{6}: 75 \% \mathrm{RDP}+$ seed inoculation with Phosphate Solubilzing Biofertilizer, $\mathrm{T}_{7}$ : $100 \%$ RDP + seed inoculation with Phosphate Solubilzing Biofertilizer. The seeds of pearlmillet were inoculated with PSB. A solution of jaggery (100 g in $500 \mathrm{ml}$ water) obtained after 15 minutes of boiling to get slurry and cooled to room temperature. The slurry was poured on the seeds and mixed to have a uniform coating of culture over the seeds. The inoculated seed were spread on a dried floor in shade for drying for about 30 minutes. The dried seeds were sown immediately and covered with soil. PSB treated seeds of pearl millet hybrid (Rana) were sown in lines by manually @ two seeds per hill with a spacing of $45 \mathrm{~cm} \times 15 \mathrm{~cm}$ on 4.08.2017 and 2.08.2018 during 2017 and 2018, respectively. Uniform application of nitrogen and potassium were given to pearl millet while phosphorus was given to pearl millet as per the treatments. The five random plants were selected from each plot, excluding the border row, for recording biometric observations of kharif pearl millet.

\section{Results and Discussion}

\section{Effect on growth attributes of pearl millet}

Growth attributes of pearl millet viz., plant height and drymatter production (Table 1) were significantly increased with increased phosphorus levels in two years of results and also in pooled data. Among the different treatments, $\mathrm{T}_{7}$ (100 per cent $\mathrm{RDP}+$ seed inoculation with $\mathrm{PSB}$ ) was recorded the highest plant height and drymatter production and which was on par with $\mathrm{T}_{4}$ (100 per cent RDP) followed by application of 75 per cent $\mathrm{RDP}+$ seed inoculation with PSB $\left(\mathrm{T}_{6}\right)$ during both years of study and in pooled data.

Higher growth attributing parameters which were recorded with $T_{7}$ and $T_{4}$ was might be due to higher level of nutrients might have facilitated better uptake and accumulation of nutrients for better growth of crop and consequently increased plant height and drymatter production. 
Table.1 Plant height $(\mathrm{cm})$ and drymatter production $\left(\mathrm{kg} \mathrm{ha}^{-1}\right)$ of pearl millet at maturity influenced by phosphorus management practices during kharif 2017, 2018 and pooled data

\begin{tabular}{|c|c|c|c|c|c|c|}
\hline \multirow[t]{2}{*}{ Treatments } & \multicolumn{3}{|c|}{ Plant height $(\mathrm{cm})$} & \multicolumn{3}{|c|}{ Drymatter production $\left(\mathrm{kg} \mathrm{ha}^{-1}\right)$} \\
\hline & 2017 & 2018 & Pooled & 2017 & 2018 & Pooled \\
\hline $\mathbf{T}_{1}-$ no $\mathbf{P}$ & 167.4 & 164.0 & 166.7 & 4571 & 4338 & 4454 \\
\hline$T_{2}-50 \%$ RDP & 173.4 & 171.7 & 172.5 & 5186 & 5044 & 5115 \\
\hline $\mathrm{T}_{3}-75 \%$ RDP & 185.8 & 183.8 & 184.8 & 6493 & 6467 & 6480 \\
\hline$T_{4}-100 \%$ RDP & 197.2 & 194.5 & 195.8 & 7876 & 7826 & 7851 \\
\hline $\mathrm{T}_{5}-50 \% \mathrm{RDP}+\mathrm{PSB}$ & 176.7 & 172.2 & 174.5 & 5771 & 5634 & 5702 \\
\hline $\mathrm{T}_{6}-75 \%$ RDP+PSB & 188.6 & 186.2 & 187.4 & 7019 & 6970 & 6995 \\
\hline $\mathrm{T}_{7}-100 \%$ RDP+PSB & 199.5 & 196.8 & 198.1 & 8081 & 7944 & 8013 \\
\hline SEm \pm & 2.85 & 3.05 & 2.78 & 319.9 & 293.0 & 286.0 \\
\hline $\mathrm{CD}(\mathrm{p}=\mathbf{0 . 0 5})$ & 8.8 & 9.4 & 8.6 & 986 & 903 & 881 \\
\hline
\end{tabular}

Table.2 Productive tillers $\mathrm{m}^{-2}$, earhead length $(\mathrm{cm})$ and test weight (g /1000 grains) of kharif pearl millet as influenced by phosphorus management practices during 2017, 2018 and pooled data

\begin{tabular}{|c|c|c|c|c|c|c|c|c|c|}
\hline \multirow[t]{2}{*}{ Treatments } & \multicolumn{3}{|c|}{2017} & \multicolumn{3}{|c|}{2018} & \multicolumn{3}{|c|}{ Pooled } \\
\hline & $\begin{array}{l}\text { Productive } \\
{\text { tillers } \mathbf{m}^{-2}}^{\text {Paller }}\end{array}$ & $\begin{array}{c}\text { Earhead } \\
\text { length }\end{array}$ & $\begin{array}{c}\text { Test } \\
\text { weight }\end{array}$ & 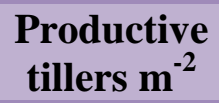 & $\begin{array}{c}\text { Earhead } \\
\text { length }\end{array}$ & $\begin{array}{c}\text { Test } \\
\text { weight }\end{array}$ & $\begin{array}{l}\text { Productive } \\
\text { tillers }\end{array}$ & $\begin{array}{l}\text { Earhead } \\
\text { length }\end{array}$ & $\begin{array}{c}\text { Test } \\
\text { weight }\end{array}$ \\
\hline$T_{1}-$ no $P$ & 25.0 & 18.9 & 7.5 & 24.0 & 18.1 & 7.0 & 24.5 & 18.5 & 7.3 \\
\hline $\mathrm{T}_{2}-50 \% \mathrm{RDP}$ & 28.7 & 20.4 & 7.2 & 26.3 & 21.7 & 6.9 & 27.5 & 21.1 & 7.1 \\
\hline $\mathrm{T}_{3^{-}} \mathbf{7 5} \% \mathrm{RDP}$ & 29.7 & 22.8 & 7.8 & 28.0 & 23.3 & 7.4 & 28.8 & 23.1 & 7.6 \\
\hline $\mathrm{T}_{4}-100 \%$ RDP & 32.3 & 26.6 & 7.9 & 31.3 & 27.2 & 7.7 & 31.8 & 26.9 & 7.8 \\
\hline $\mathbf{T}_{5}-50 \%$ RDP+PSB & 28.0 & 22.0 & 7.3 & 27.0 & 22.8 & 6.9 & 27.5 & 22.4 & 7.1 \\
\hline $\mathrm{T}_{6}-75 \%$ RDP+PSB & 30.3 & 24.4 & 8.0 & 28.7 & 24.0 & 7.8 & 29.5 & 24.2 & 7.9 \\
\hline $\mathrm{T}_{7}-100 \% \mathrm{RDP}+\mathrm{PSB}$ & 33.3 & 28.4 & 8.2 & 33.0 & 27.9 & 8.0 & 33.2 & 28.2 & 8.1 \\
\hline SEm \pm & 1.33 & 1.24 & 0.48 & 1.34 & 1.39 & 0.45 & 1.18 & 1.05 & 0.34 \\
\hline $\mathrm{CD}(\mathbf{p}=\mathbf{0 . 0 5})$ & 4.1 & 3.8 & NS & 4.1 & 4.3 & NS & 3.6 & 3.2 & NS \\
\hline
\end{tabular}


Table.3 Grain yield $\left(\mathrm{kg} \mathrm{ha}^{-1}\right)$, Stover yield $\left(\mathrm{kg} \mathrm{ha}^{-1}\right)$ and harvest index $(\%)$ of kharif pearl millet as influenced by phosphorus management practices during 2017, 2018 and pooled data

\begin{tabular}{|c|c|c|c|c|c|c|c|c|c|}
\hline \multirow[t]{2}{*}{ Treatments } & \multicolumn{3}{|c|}{2017} & \multicolumn{3}{|c|}{2018} & \multicolumn{3}{|c|}{ Pooled } \\
\hline & $\begin{array}{l}\text { Grain } \\
\text { yield }\end{array}$ & $\begin{array}{c}\text { Stover } \\
\text { yield }\end{array}$ & $\begin{array}{c}\text { Harvest } \\
\text { index }\end{array}$ & $\begin{array}{l}\text { Grain } \\
\text { yield }\end{array}$ & $\begin{array}{c}\text { Stover } \\
\text { yield }\end{array}$ & $\begin{array}{c}\text { Harvest } \\
\text { index }\end{array}$ & $\begin{array}{l}\text { Grain } \\
\text { yield }\end{array}$ & $\begin{array}{c}\text { Stover } \\
\text { yield }\end{array}$ & $\begin{array}{c}\text { Harvest } \\
\text { index }\end{array}$ \\
\hline $\mathbf{T}_{1}-$ no $\mathbf{P}$ & 1619 & 3277 & 33.1 & 1482 & 3028 & 32.7 & 1555 & 3153 & 33.0 \\
\hline $\mathbf{T}_{2^{-}}-50 \%$ RDP & 1958 & 3617 & 35.6 & 1818 & 3449 & 34.7 & 1888 & 3533 & 35.1 \\
\hline $\mathrm{T}_{3^{-}} \mathbf{7 5} \% \mathrm{RDP}$ & 2514 & 4139 & 37.8 & 2460 & 4043 & 38.2 & 2487 & 4091 & 38.1 \\
\hline $\mathrm{T}_{4}-100 \% \mathrm{RDP}$ & 2952 & 5204 & 36.2 & 2809 & 4976 & 36.0 & 2881 & 5090 & 36.1 \\
\hline $\mathrm{T}_{5}-\mathbf{5 0} \% \mathrm{RDP}+\mathrm{PSB}$ & 2173 & 3865 & 35.9 & 1931 & 3592 & 34.9 & 2052 & 3729 & 35.5 \\
\hline $\mathrm{T}_{6}-75 \% \mathrm{RDP}+\mathrm{PSB}$ & 2602 & 4467 & 36.8 & 2537 & 4300 & 37.0 & 2569 & 4384 & 36.9 \\
\hline $\mathrm{T}_{7-} 100 \% \mathrm{RDP}+\mathrm{PSB}$ & 2996 & 5313 & 36.1 & 2876 & 5120 & 35.9 & 2936 & 5216 & 36.0 \\
\hline SEm \pm & 124.1 & 225.4 & 2.01 & 127.0 & 229.9 & 1.65 & 116.2 & 208.9 & 1.19 \\
\hline $\mathrm{CD}(p=0.05)$ & 382 & 695 & NS & 391 & 708 & NS & 358 & 644 & NS \\
\hline
\end{tabular}


Further, beneficial effect of $\mathrm{P}$ attributed towards root proliferation and synthesis of protoplasm gave higher pace of dry matter production. Inoculation of PSB might helped in enhanced production of growth promoting substances and reduced phosphorus fixation by PSB chelating effects and also solubilization of unavailable forms of phosphorus. These results are supported by Kumar et al., (2014) and Rasal and Patil (1993).

\section{Effect on yield attributes and yields $\left(\mathrm{kg} \mathrm{ha}^{-1}\right)$}

Yield attributes such as earhead length $(\mathrm{cm})$, productive tillers per $\mathrm{m}^{-2}$ (Table 2) were significantly varied among the different treatments imposed and while test weight ( $\mathrm{g}$ per 1000 seeds) was not significantly influenced by the different treatments (Table 2) during the two years of research and also pooled data. Significant improvement in grain and stover yields (Table 3) of pearl millet. Among the different treatments, the treatments which received 100 per cent RDP + seed inoculation with PSB $\left(\mathrm{T}_{7}\right)$ were significantly recorded the highest yield attributes i.e. earhead length $(28.4,27.9$ and 28.2) and productive tillers $\mathrm{m}^{-2}(33.3,33.0$ and 33.2) during first, second year study and in pooled data respectively. Grain yield and stover yield (2996 kg ha ${ }^{-1}$ and $5313 \mathrm{~kg} \mathrm{ha}^{-1}$ ) during first year $\left(2876 \mathrm{~kg} \mathrm{ha}^{-1}\right.$ and $5120 \mathrm{~kg}$ $\mathrm{ha}^{-1}$ ) during second year and in pooled data (2936 kg ha ${ }^{-1}$ and $5216 \mathrm{~kg} \mathrm{ha}^{-1}$ ) recorded with same treatment. However, it was found to be at par with 100 per cent RDP $\left(\mathrm{T}_{4}\right)$ during 2017, 2018 and in pooled data also. The lowest yields were registered with the treatment, $\mathrm{T}_{1}$ (no phosphorus).

Phosphorus is one of the major essential nutrient and needed in adequate amounts in the available form for the growth and production of plants. Phosphorus is associated with several vital functions and is responsible for many characteristic of plant growth. As a component of ATP, phosphorus is needed for the conversion of light energy to chemical energy (ATP) during photosynthesis. Phosphorus is also involved in better root growth enhanced nutrient uptake and translocation of photosynthates from source to sink which might have aided in production of growth promoting substances. Increased photosynthetic activity results in higher accumulation of photosynthates. Further, these are translocated to sink due to better development of source-sink relationships. All these factors might have helped in increased yield attributes which further resulted in increased yields of pearl millet.

The probable reason may be that the increasing $\mathrm{P}$ levels and its comination with biofertilizer resulted in greater accumulation of carbohydrates, protein and their translocation, which in turn, improved all growth attributing characters resulting in more stover yield. Besides this, the addition of NPK provided adequate balanced quantity of plant nutrient and also increased mobility, absorption and translocation of nutrient leading to increased production of photosynthates by the crop resulting in increased biomass accumulation.

Singh and Agrawal (2004), Chaurasia et al., (2006), Nanwal (1991), Vyas et al., (1992) and Yakadari et al., (1994) also reported linear increase in the yield of pearimillet with increasing doses of fertilizer $\mathrm{P}$ with combination of biofertilizers over control.

\section{Harvest Index (HI)}

The results (Table 3) revealed that different phosphorus management treatments had no significant effect on harvest index of pearl millet. These results are conforms with findings of Singh and Agarwal (2004). 


\section{References}

Chaurasia, M., Chauhan, D.R and Singh, J. 2006. Effect of irrigation, nitrogen and phosphorous levels on fodder production of bajra (Pennisetum glaucum) - A local race of bajra. Forage Research. 32 (2): 128-129.

Kumar, A., Kumar, P., Gera, R., Kumar, M and Ishmadhu. 2014. Effect of integrated nutrient management on crop yield, available nutrient status and microbial status of soil in pearl milletwheat cropping system. Crop Research. 45 (1, 2 \& 3): 22-26.

Nanwal, RK. (1991). Intercropping studies in rainfed pearlmillet under different planting systems and fertility levels. Ph.D. thesis, Division of Agronomy, IARI, New Delhi.

Rasal, P.H and Patil, P.L. 1993. Effect of organic matter with microbial inoculants on pearlmillet. Journal of Indian Society of Soil Science. 41 (1): 84-86.

Singh R. K, Chakraborty D, Garg R N, Sharma P K and Sharma U C. 2010. Effect of different water regimes and nitrogen application on growth, yield, water use and nitrogen uptake by pearlmillet (Pennisetum glaucum). Indian Journal of Agricultural Science. 80(3): 213-216.

Singh, D.K and Agarwal, R.L. 2004. Nitrogen and phosphorous nutrition of pearl millet (Pennisetum glaucum) grown in sole and inter cropping systems under rainfed conditions. Indian Journal of Dryland Agriculture Research and Development.49 (3): 151-153.

Tisdale, S.L., Nelson, W.L., Beaton, J.D. and Havlin, J.L. 1995. Soil Fertility and Fertilizers. Fifth edition, New Delhi. Prentice Hall of India Pvt. Ltd. pp. 6275.

Vyas, S.H., Patel, J.C., Patel, B.S. and Sukhadia, N.M. (1992). Response of summer pearlmillet to irrigation, nitrogen and phosphorus. Indian Journal of Agronomy 37(4): 819-821.

www.Indiabudget.nic.in/2016-17

Yakadri, M., Gautam, R.C. and Kaushik, S.K. (1994). Effect of intercropping and fertilizer levels on yield and quality of rainfed pearlmillet (Pennisetum g/aucum). Indian Journal of Agronomy 39(4): 528-531.

\section{How to cite this article:}

Sowjanya, A., Ch. Pulla Rao, K. Mosha, Ch. Sujani Rao and Ashoka Rani, Y. 2019. Growth, Yield Attributes and Yield of Pearl Millet as Influenced by Phosphorus Management Practices in Kharif Pearl Millet. Int.J.Curr.Microbiol.App.Sci. 8(06): 3143-3148. doi: https://doi.org/10.20546/ijcmas.2019.806.375 